\title{
Social Defeat Stress-Induced Behavioral Responses are Mediated by the Endogenous Kappa Opioid System
}

\author{
Jay P McLaughlin', Shuang Li ${ }^{2}$, Joseph Valdez ${ }^{2}$, Theodore A Chavkin² and Charles Chavkin*,2 \\ 'Department of Psychology, Northeastern University, Boston, MA, USA; ²Department of Pharmacology, University of Washington, Seattle, \\ WA, USA
}

\begin{abstract}
Previous studies have demonstrated that repeated forced-swim stress-induced behaviors (including analgesia, immobility, and increased drug reward) were mediated by the release of endogenous prodynorphin-derived opioid peptides and subsequent activation of the kappa opioid receptor (KOR). We tested the generality of these effects using a different type of stressful situation: repeated social defeat. C57BI/6 mice subjected to social defeat stress (SDS) over 3 days showed a characteristic stress-induced immobility and defeatedpostural response, as well as stress-induced analgesia (SIA). Daily pretreatment with the KOR antagonist nor-binaltorphimine (nor-BNI, $10 \mathrm{mg} / \mathrm{kg}$, i.p.) blocked the SIA and significantly reduced the stress-induced immobility on the second and third days of SDS exposure. In contrast, prodynorphin gene-disrupted mice showed no significant increase in immobility, socially defeated postures, or SIA following repeated exposure to SDS. Since both stress and the kappa opioid system can modulate the response to drugs of abuse, we tested the effects of SDS on cocaine-conditioned place preference (CPP). SDS-exposed mice conditioned with cocaine (I5 mg/kg, s.c.) showed significant potentiation of place-preference for the drug-paired chamber over the responses of unstressed mice. Nor-BNI pretreatment blocked stress-induced potentiation of cocaine-CPP. Consistent with this result, mice lacking the prodynorphin gene did not show stressinduced potentiation of cocaine-CPP, whereas wild-type littermates did. The findings suggest that chronic SDS may activate the kappa opioid system to produce analgesia, immobility, social defeat postures, and resulting in a potentiation of the acute rewarding properties of cocaine.
\end{abstract}

Neuropsychopharmacology (2006) 31, I24 I-1248. doi: I 0.1038/sj.npp. I 300872; published online 17 August 2005

Keywords: kappa; opioid; dynorphin; stress; depression; cocaine; conditioned place preference

\section{INTRODUCTION}

Stress has long been associated with increased initiation and reinstatement of drug abuse (Goeders, 2002; Stewart, 2003). In humans, stress increases craving and risk of relapse of drug use in addicts (Epstein and Preston, 2003; Sinha et al, 1999). In animal models, chronic stress exposure increases the drug craving (Shaham et al, 2000, 2003; Sanchez et al, 2003). A better understanding of these interactions is likely to provide important therapeutic insights. Previously, we found that repeated forced-swim stress (FSS) preceding cocaine conditioning nearly doubled the subsequent place preference (CPP) response in male C57Bl/6 mice (McLaughlin et al, 2003). The stress-induced potentiation of the CPP was completely blocked by treatments that disrupted functioning of the dynorphin (DYN)/kappa opioid system.

\footnotetext{
*Correspondence: Dr C Chavkin, Department of Pharmacology, Box 357280, University of Washington, Seattle, WA 98195-7280, USA, Tel: + 206543 4266, Fax: + 2066853822 ,

E-mail: cchavkin@u.washington.edu

Received 29 April 2005; revised 5 July 2005; accepted II July 2005

Online publication: 15 July 2005 at http://www.acnp.org/citations/ Npp07| 505050276/default.pdf
}

Mice either pretreated with the kappa opioid receptor (KOR) antagonist norbinaltorphimine (nor-BNI), or possessing disrupted prodynorphin or KOR genes showed normal cocaine-CPP but failed to show stress-induced potentiation (McLaughlin et al, 2003, 2005). Those results suggested that the DYN/kappa opioid system was necessary for the stress-induced potentiation of the cocaine-CPP.

A role for DYN as a mediator of the stress response had been previously suggested by Carlezon and co-workers (Pliakas et al, 2001; Mague et al, 2003) who showed that kappa receptor antagonists had antidepressant-like effects in the repeated forced-swim test. In addition, stress-induced activation of CREB has been shown to increase DYN expression and modulate the response to cocaine (Carlezon et al, 1998; Newton et al, 2002). The role of DYN and the KOR in controlling responses to cocaine is somewhat controversial. Shippenberg and co-workers suggest that endogenous dimorphism suppress cocaine reward since KORs topically inhibit the enhanced dopamine neurotransmission in nucleus acumens following cocaine (Chefer $\mathrm{et} \mathrm{al}$, 2005). In contrast, we found that pharmacological activation of the kappa receptor prior to cocaine could potentiate the subsequent cocaine-CPP (McLaughlin et al, 2005). A better 
understanding how endogenous DYNs mediate the responses to stress and affect responses to cocaine may be important in understanding mechanisms of stress-induced depression and stress-induced drug craving.

To address these issues, we tested whether other forms of stress were able to produce effects on cocaine-CPP similar to repeated FSS. Repeated swim stress evokes strong efforts to escape and involves intense physical exertion. As such, the mechanisms and pathways mediating the responses to swim stress may differ from those mediating the responses to other forms of repeated stress not involving intense physical exertion. Thus, an important assessment of the generality of the hypothesis would be to determine whether the DYN-kappa system contributes to the potentiation of the rewarding properties of cocaine induced by other repeated stressors. Repeated social-defeat stress using the procedures developed by Miczek et al provides a more naturalistic model of stress characterized by aggressive interactions that are intense, unpredictable, and inescapable. Social-defeat stress in rats has been shown to enhance cocaine self-administration and produce a sensitization to the locomotor stimulating effects of cocaine (Covington and Miczek, 2001). In mice, social-defeat stress produced behavioral sensitization to the locomotor effects of cocaine (Nikulina et al, 2004). In the current studies, we asked whether repeated social defeat stress (SDS) also potentiates cocaine conditioned place preference (CPP) and whether that effect could also be prevented by nor-BNI or DYN gene disruption of the endogenous kappa opioid system.

\section{MATERIALS AND METHODS}

\section{Animals and Housing}

Male C57Bl/6 mice (Charles River Laboratories, Wilmington, MA) weighing 22-32 g (12-16 weeks old) were used in these experiments. Mice were group-housed, 2-4 per cage, in self-standing plastic cages $(28 \mathrm{~cm} L \times 16 \mathrm{~cm} W \times 13 \mathrm{~cm}$ $H$ ) using 'Bed-o'Cob' for home bedding within the animal core facility at the University of Washington, and maintained in a specific pathogen-free housing unit. Mice were transferred 1 week prior to training into a colony room adjacent to the testing room to acclimatize to the testing environment. Housing rooms were illuminated on a $12-\mathrm{h}$ light-dark cycle with lights on at 0700 . Food pellets and water were available ad libitum. Procedures with mice were approved by the institutional Animal Care and Use Committee in accordance with the 1996 NIH Guide for the Care and Use of Laboratory Animals, and mice were inspected regularly by veterinary staff to ensure compliance.

\section{Breeding and Genotyping of Prodynorphin Knockout Mice}

Homozygous prodynorphin knockout (KO) (-/-) mice were prepared by homologous recombination as described (Sharifi et al, 2001) and provided for this study. Animals were back-crossed for $>10$ generations with C57Bl/6 mice, and heterozygote breeding pairs were used to generate homozygotic $\mathrm{KO}$ mice of each type and paired wild-type
(WT) littermate controls for this study. Individual mice were genotyped by extracting DNA from tail samples that was then used as template in a pair of PCR reactions as described previously (McLaughlin et al, 2003). The prodynorphin gene-disrupted animals show no discernible differences from WT littermates in growth, lifespan, overt behavior, or locomotor activity (Sharifi et al, 2001).

\section{Drugs}

Cocaine hydrochloride (National Institute on Drug Abuse, Bethesda, MD) and nor-BNI (Sigma, St Louis, MO) were dissolved in sterile physiological saline. Drugs and vehicle were delivered in injection volumes of $0.1 \mathrm{ml} / 10 \mathrm{~g}$ body weight.

\section{Social Defeat Stress}

To induce SDS, a single $\mathrm{C} 57 \mathrm{Bl} / 6$ or transgenic mouse (the 'intruder') was transiently placed in the home cage of a resident male mouse (the 'aggressor') in a procedure adapted from previous studies (Miczek, 1979; Rodgers and Randall, 1986; Spina et al, 2000; Kabbaj et al, 2001; Nikulina et al, 2004). SDS behaviors of the intruder mouse during a confrontation with the resident aggressor were recorded. Specifically, resident C57Bl/6 male mice were housed with a normal cycling female to enhance territorial behavior and aggressiveness. Females were removed from the resident's cage before starting the social stress procedure, and the intruder mouse introduced for a 20-min trial. The number of seconds an intruder mouse maintained social defeat posture in the presence of an aggressor was recorded throughout five trials by an observer blind to genotype or prior drug treatment. Defeat was identified as the display of a submissive (supine) posture for at least $4 \mathrm{~s}$ during an agonistic interaction consisting of: immobility (four paws on ground, orienting toward resident), escape (fleeing the resident), crouching (four paws on ground, not orienting toward resident), or defensive upright stance (standing still and erect with forepaws extended) (as in Miczek, 1979; Kabbaj et al, 2001). Intruder mice were pretreated with vehicle $(0.9 \%$ saline intraperitoneal (i.p.)) or nor-BNI $(10 \mathrm{mg} / \mathrm{kg}$, i.p.) $1 \mathrm{~h}$ prior to each day's first social defeat trial. Intruders were exposed to SDS from 0930 to 1230 in the initial daily trial, then again $3 \mathrm{~h}$ later in the second daily trial.

\section{Antinociceptive Testing Using the $55^{\circ} \mathrm{C}$ Warm-Water Tail-Withdrawal Assay}

The response latency for the mouse to withdraw its tail following immersion in $55^{\circ} \mathrm{C}$ water was taken as the endpoint (Vaught and Takemori, 1979), modified as previously described (McLaughlin et al, 2003). A maximum score was assigned (100\%) to animals not responding within $15 \mathrm{~s}$ to avoid tissue damage. Antinociception (maximal possible effect) was calculated by the following equation: \% MPE $=100 \times($ test latency-control latency) $/$ (15-control latency). Antinociceptive testing followed the completion of SDS exposure within 5-9 min, consistent with previous studies (McLaughlin et al, 2003). 


\section{Conditioned Place Preference}

Mice were used in place-conditioning studies using a threecompartment box, similar to the methods utilized by Cunningham et al (1998) and Carlezon et al (1998). The apparatus and conditioning procedures were as previously described (McLaughlin et al, 2003). The compartmentalized box was divided into two equal-sized outer sections $\left(25 \times 25 \times 25 \mathrm{~cm}^{3}\right)$ joined by a small central compartment $\left(8.5 \times 25 \times 25 \mathrm{~cm}^{3}\right)$ accessed through a single doorway $\left(3 \times 3 \mathrm{~cm}^{2}\right)$. The compartments differ in wall striping (vertical $v s$ horizontal alternating black and white lines, $1.5 \mathrm{~cm}$ in width) and floor texture (wood chips $v s$ 'Bed-o' (ob'). Mice were screened for initial preferences on the morning of day 1 by placing mice in the small central compartment and allowing them to move freely throughout the entire apparatus for $30 \mathrm{~min}$ while recording time spent in the two outer compartments. The CPP apparatus itself was found to be unbiased. Mice $(n=90)$ spent an equal amount of time in the chamber with vertical stripes and wood chip bedding $(658 \pm 19.5 \mathrm{~s})$ and the chamber with horizontal stripes and 'Bed-o'-Cob' bedding $(669 \pm 15.2 \mathrm{~s})$. On day 2, mice were injected subcutaneously (s.c.) with $15 \mathrm{mg} / \mathrm{kg}$ cocaine and immediately placed in the compartment opposite to that in which they had spent more time in the pre-conditioning test, for $30 \mathrm{~min}$ (although the conditioning apparatus was unbiased, we randomized the design by making the drug-paired chamber the one that the individual mouse preferred less during the pre-conditioning trial). After $4 \mathrm{~h}$, mice received saline $(0.1 \mathrm{ml} / 10 \mathrm{~g}$ body wt., s.c.) and immediately confined for $30 \mathrm{~min}$ to the opposite outer compartment. On day 3 , mice again were conditioned first with cocaine, followed by saline $4 \mathrm{~h}$ later, in the appropriate compartments. On day 4, mice were placed in the small central compartment and allowed to freely roam between the two outer compartments for $30 \mathrm{~min}$, and movement through the chambers was detected by infrared beam sensors (LabLinc, Coulbourn Instruments, Allentown, PA). Time spent in the two outer compartments was then calculated by GraphicState 2 software (Coulbourn Instruments, Allentown, PA). Note that results are plotted as the difference in the times spent on the drug-paired side $v s$ the vehicle-paired side. Therefore, a positive value demonstrates the animal's preference for the drug-paired side. The lack of apparent bias in the apparatus was consistent with our previous report that mice trained with saline in both compartments showed no significant preference (McLaughlin et al, 2003). In that study, we also found that mice given saline following stress in the first compartment and saline alone in the second developed no significant place preference (McLaughlin et al, 2003). Prior exposure to stress did not significantly affect the difference between time spent in the middle compartment after cocaine training and time in the middle compartment before cocaine training (unstressed mice $-40 \pm 27 \mathrm{~s}$; stressed mice $-81 \pm 32 \mathrm{~s}$, Student's $t$-test $p>0.05)$.

\section{Data Analysis}

Behavioral data were analyzed by the Student's $t$-test or either one-way or two-way analysis of variance (ANOVA) as appropriate. Data for the CPP study did not meet the assumptions of normal distribution necessary for parametric evaluation, and Kruskal-Wallis One-way ANOVA was used for the analysis. Significant results demonstrated by ANOVA were further analyzed for significance with LSD multiple-comparison post hoc test (NCSS 2001 Software, Kaysville, Utah). Data are presented as means \pm SEM of the animal treatment group, with significance set at $p<0.05$.

\section{RESULTS}

\section{SDS-Induced Analgesia was Mediated by the KOR and Prodynorphin Gene Derived Opioids}

C57Bl/6 WT mice were treated with vehicle and exposed to the SDS in five trials over 3 days. After each trial, tailwithdrawal latency in the $55^{\circ} \mathrm{C}$ warm-water tail-withdrawal assay was significantly increased after SDS exposure (Day 1 : $\mathrm{F}_{2,93}=9.60 ;$ Day 2: $\mathrm{F}_{2,93}=9.09 ;$ Day 3: $\mathrm{F}_{1,60}=7.05 ;$ all $p<0.01$, one-way ANOVA, Figure 1a). The SDS-induced analgesia (SIA) was blocked by daily i.p. pretreatment with the KOR antagonist nor-BNI (10 mg/kg i.p.) prior to stress exposure (Day 1: $\mathrm{F}_{2,76}=0.93$; Day 2: $\mathrm{F}_{2,75}=1.70$; Day 3: $\mathrm{F}_{1,49}=1.33$; all $p>0.05$, one-way ANOVA, Figure $1 \mathrm{~b}$ ). $\mathrm{C} 57 \mathrm{Bl} / 6$ mice lacking the prodynorphin gene-derived opioid peptides (DYN $(-/-)$ mice) and their WT littermates were also exposed to SDS. Consistent with the effects of nor-BNI, $\mathrm{DYN}(-/-)$ mice demonstrated no significant difference in tail-withdrawal latency after SDS (Day 1: $F_{2,33}=0.26$; Day 2: $F_{2,33}=0.16$; Day 3: $F_{1,22}=0.62$; all $p>0.05$, one-way ANOVA, Figure 1c). Nor-BNI had no significant effect on $\mathrm{DYN}(-/-)$ mice (data not shown). The stress-induced increase in tail-flick latency of the WT littermate mice on each day was equivalent (across trials, $\mathrm{F}_{4,50}=0.64, p>0.05$, one-way ANOVA), suggesting a consistent activation of the nor-BNI sensitive, endogenous opioid system.

\section{Immobility and Defeat Behaviors Induced by SDS are Prevented by Nor-BNI and Prodynorphin Gene Disruption}

Rodents exposed to SDS displayed characteristic responses of immobility and socially defeated postures (Miczek et al, 2004). As defined by the description presented in the Materials and methods section, the immobility resulting from SDS after vehicle pretreatment increased upon repeated trials. Two-way ANOVA (factor trial and factor nor-BNI, $\quad F_{\text {trial } / 4,178}=2.38, p=0.05 ; \quad F_{\text {nor-BNI } / 1,178}=13.93$, $p<0.001 ; \mathrm{F}_{\text {trial } \times \text { nor-BNI/4,178 }}=1.05, p>0.05$ ) showed there were significant effects of nor-BNI, but no trial effects or interaction effects. Similar to results using FSS presented previously (McLaughlin et al, 2003), C57Bl/6 WT mice pretreated with vehicle or nor-BNI demonstrated no differences in time spent immobile on the first day of testing. However, when mice were repeatedly challenged by SDS over the next 2 days, nor-BNI pretreatment significantly reduced the time spent in socially defeated, immobile postures $(p<0.05$; LSD multiple-comparison post hoc test, Figure 2, trials 4-5).

DYN $(-I-)$ mice and their WT littermates were pretreated daily with vehicle and exposed to SDS. WT littermates demonstrated an increased immobility over trials, which were not significantly different from C57Bl/6 WT mice (data 
not shown). Two-way ANOVA (factor trial and factor $\mathrm{DYN}, \mathrm{F}_{\text {trial } / 4,156}=0.89, p>0.05 ; \mathrm{F}_{\mathrm{DYN} / 1,156}=26.47, p<0.001$; $\left.\mathrm{F}_{\text {trial }} \times \mathrm{DYN} / 4,156=2.7, p<0.05\right)$ showed there were significant $\mathrm{DYN}(-/-)$ and interaction effects. Although during earlier trials (trials 1 and 2), there was no significant differences in the socially defeated, immobility responses between the
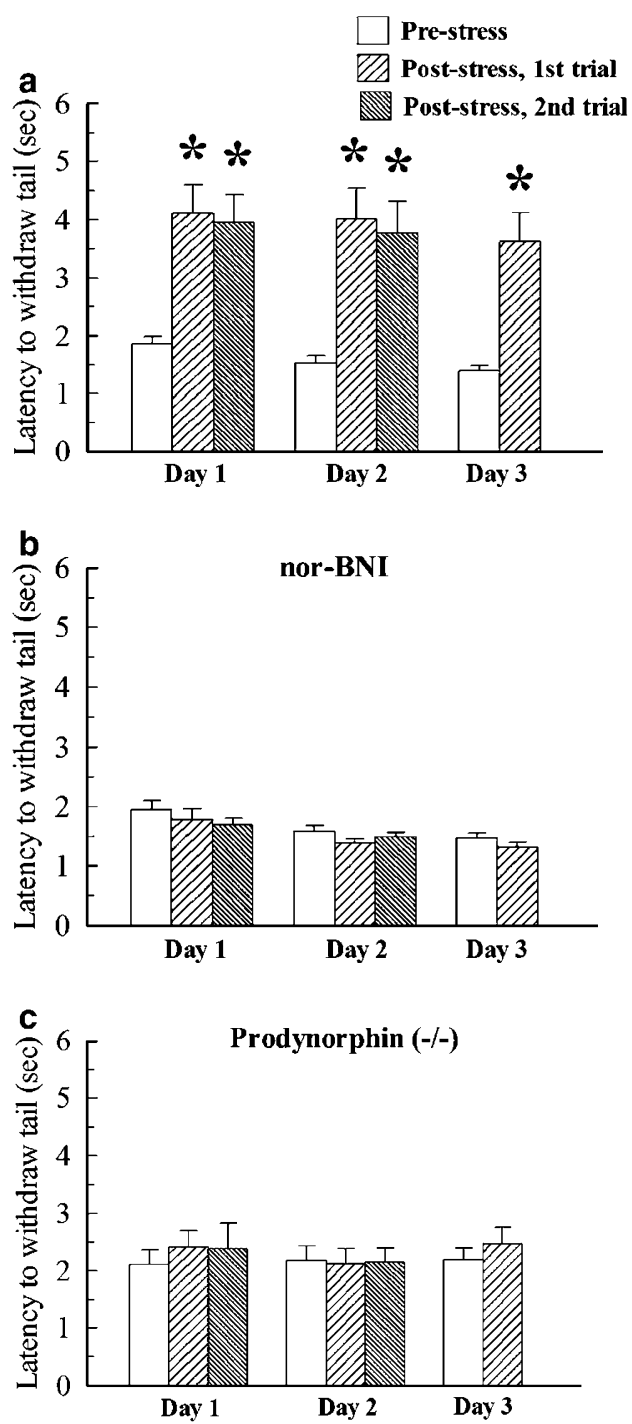

Figure I Social defeat stress (SDS)-induced analgesia is blocked by pretreatment with nor-BNI or prodynorphin gene derived disruption. Tailwithdrawal latencies presented were obtained 5-9 min after exposure to $\mathrm{SDS}$, on the first, second, or third day. Mice were tested in the $55^{\circ} \mathrm{C}$ warmwater tail-withdrawal assay before (open bars) and after exposure to the SDS (thatched bars), as described in 'Materials and methods'. (a) On each day, C57BI/6 mice pretreated with vehicle i.p. demonstrated a tailwithdrawal response that was approximately doubled after social stress. (b) Pretreatment $60 \mathrm{~min}$ prior to SDS with the KOR-selective antagonist, nor$\mathrm{BNI}(10 \mathrm{mg} / \mathrm{kg}$, i.p.) did not significantly change baseline tail-withdrawal latencies (open bars, b), but blocked the increase in SIA produced by SDS (thatched bars, b). (c) Similar to nor-BNI, disruption of the prodynorphin gene prevented SDS-induced analgesia in vehicle-treated mice in each trial over 3 days. * significantly different from matching pre-stress latencies on day I, day 2, $p<0.05$, as determined by one-way ANOVA followed by Fisher's LSD multiple-comparison post hoc test. * significantly different than matching pre-stress latencies on day $3, p<0.05$, as determined by Student's $t$-test. Bars represent $n=23-32$ WT or 12 DYN $(-/-)$ mice.
$\mathrm{DYN}(-/-)$ mice and WT mice, repeated SDS trials thereafter revealed a significant reduction in later trials in the duration of social defeat postures and immobility displayed by the prodynorphin $\mathrm{KO}$ mice as compared to their WT mice $(p<0.05$; LSD multiple-comparison post hoc test, Figure 2, trials 3-5). Notably, the inhibitory effects of prodynorphin gene disruption on social defeat posture and immobility during the later SDS trials were consistent with the effects of nor-BNI on WT mice. The results suggest that the DYN/kappa system contributes to the increasing response during chronic stress rather than to the acute social stress-induced immobility.

\section{Exposure to SDS Potentiates Cocaine-CPP in a Nor-BNI Sensitive Manner}

As many stressors have been demonstrated to potentiate the rewarding effects of abused drugs (Haile et al, 2001; Kabbaj et al, 2001; McLaughlin et al, 2003), we asked if repeated SDS could potentiate cocaine-CPP and if that potentiation was mediated by a nor-BNI-sensitive mechanism. Initially $\mathrm{C} 57 \mathrm{Bl} / 6$ mice were tested in the CPP apparatus before drugtreatment to obtain preconditioning responses for subsequent comparisons. Animals were exposed to SDS over 3 days or left in home cages in conjunction with conditioning on the afternoon of day 2 with cocaine $(15 \mathrm{mg} / \mathrm{kg}$, s.c.), followed by saline (see protocol, Figure 3a). After conditioning, unstressed, control C57Bl/6 mice demonstrated a significant increase in the time spent in the drug-paired chamber than prior to conditioning $(p<0.001$, Student's $t$-test), and spent significantly more time in the drug-paired chamber than the saline-paired chamber (Figure 3b). Mice

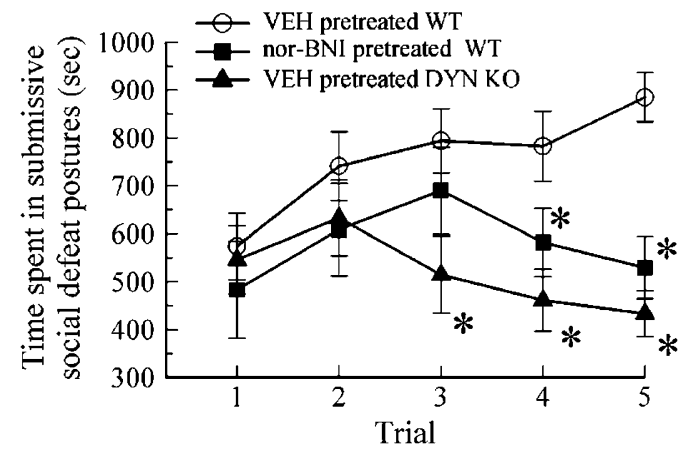

Figure 2 Time spent in socially defeated postures is reduced on the second and third day of testing by pretreatment with nor-BNI or prodynorphin gene disruption. The time mice spent immobile and in socially defeated postures during each trial exposure to social-defeat stress was measured over five trials across 3 days. WT mice received either vehicle or nor-BNI I h prior to daily SDS. Prodynorphin gene disrupted mice received vehicle. All mice exposed to two trials of SDS on day I demonstrated no difference in immobility response on the first day, regardless of pretreatment. However, mice pretreated with either nor-BNI or lacking prodynorphin spent significantly less time immobile and in socially defeated postures from the second SDS trial on the second and third days than vehicle-treated WT mice. * significant difference between immobility and socially defeated postural responses of stress-exposed vehicletreated and nor-BNI treated WT mice or DYN $(-/-)$ mice, $p<0.05$, as determined by two-way ANOVA followed by Fisher's LSD multiplecomparison post hoc test. 
a

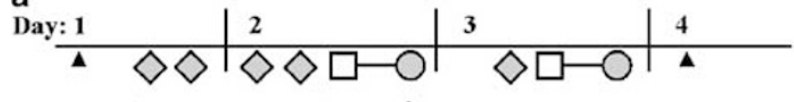

$\Delta$ Preference test, $30 \mathrm{~min} \diamond$ Social defeat stress exposure

Cocaine conditioning, $30 \mathrm{~min}$

Vehicle conditioning, $30 \mathrm{~min}$

b

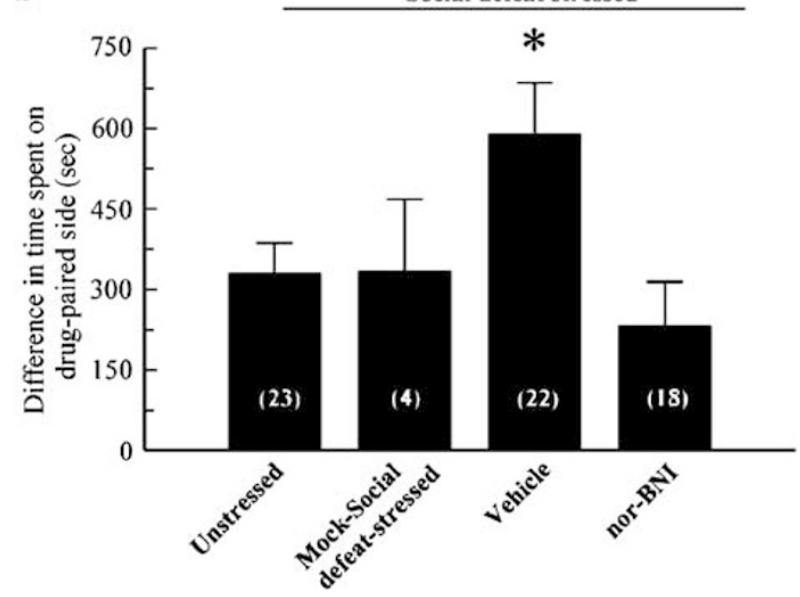

Figure 3 Exposure to SDS produces a nor-BNI sensitive potentiation of cocaine-CPP. (a) Schematic of training paradigm. The CPP protocol was as described in 'Materials and methods.' Preference testing allowed mice to move freely for $30 \mathrm{~min}$ in the morning to measure preconditioning and subsequent responses for either of two conditioning chambers as described in Materials and methods (represented here with triangles). Following assessment of preconditioning preference, mice were exposed to repeated SDS over the next $72 \mathrm{~h}$ as detailed in Materials and methods (diamonds) or allowed to remain in home cages without stress. Within 10 min after SDS exposure on day 2, mice were administered cocaine $(15 \mathrm{mg} / \mathrm{kg}, \mathrm{s.c}$.) and confined to the drug-paired box for a 30-min conditioning session (squares). After $4 \mathrm{~h}$, mice were administered vehicle and confined to the vehicle-paired box for a 30-min conditioning session (circles). After a final SDS exposure on the third day (diamond), cocaine and saline conditioning was repeated, separated again by $4 \mathrm{~h}$ (represented by the joined square and circle icons, day 3). On day 4, the final preference test was performed blind to determine the effect of treatment and conditioning on place preference. (b) Preference test data demonstrates a nor-BNI-sensitive, SDS-induced potentiation of cocaine-CPP. Preferences are given as difference between time spent in drug-paired chamber and time in saline-paired chamber during the $30-\mathrm{min}$ trial. A positive value represents greater time spent in the drug-paired chamber. Mice were divided into four groups. The first group was unstressed, remaining in home cages and not exposed to SDS prior to 2 days of cocaine and saline conditioning as described in 'Materials and methods.' The second group was administered vehicle and exposed to a novel, unoccupied environment with a littermate ('Mock social stress') prior to cocaine conditioning. The third group was administered vehicle and exposed to SDS prior to 2 days of cocaine and saline conditioning. The fourth group was administered nor-BNI and exposed to the SDS as described above, then conditioned over two days with cocaine and saline. After conditioning, all four groups demonstrated an increase in time spent in the cocaine-paired chamber that was significantly greater than the time spent in that chamber prior to conditioning, an example of CPP. Control unstressed mice, mock social-defeat stressed, and SDS-exposed mice pretreated with nor-BNI demonstrated an equivalent degree of cocaine-CPP. In contrast, vehicle-treated mice exposed to SDS demonstrated a significant potentiation over the unstressed animals responses. * significant difference in cocaine-CPP compared with unstressed mice; $p<0.05$, as determined by Kruskal-Wallis one-way ANOVA Ranks followed by Fisher's LSD multiple-comparison post hoc test (The behavioral data did not meet the assumptions of normal distribution necessary to permit parametric evaluation). Bars represent $n=18-23$ mice, except mock social stress group, for which $n=4$ mice. pretreated with vehicle and exposed to SDS prior to cocaine conditioning developed an even larger preference for the cocaine-paired chamber. Preference for the drug-paired chamber of mice previously stressed was nearly twice that of mice not subjected to repeated social stress $(p<0.05$; LSD multiple-comparison post hoc test followed by KruskalWallis One way ANOVA, $H=9.2, p<0.05$, Figure $3 b$ ). The increase in the cocaine-CPP was not due to exposure to a novel environment prior to cocaine exposure. Mice placed in a novel cage with a littermate ('Mock social stress') and then place-conditioned with cocaine demonstrated a place preference that was significantly greater than the initial preference $(p<0.001$, Student's $t$-test $)$, but no different than the response of unstressed, control mice $(p>0.05$, Figure 3b, LSD multiple-comparison post hoc test). Nor-BNI pretreatment of SDS-exposed mice blocked the potentiation of the cocaine-CPP response (Figure 3b). Nor-BNI pretreated mice exposed to repeated SDS demonstrated a significant cocaine-CPP response over the preconditioned response $(p<0.001$, Student's $t$-test $)$ that was not significantly different from the response produced by the unstressed mice ( $p>0.05$; Figure $3 \mathrm{~b}$, LSD multiple-comparison post hoc test). This nor-BNI treatment was shown previously not to affect cocaine-CPP in the absence of stress (McLaughlin et al, 2003). The nor-BNI data suggest that chronic SDS-induced activation of KOR may have potentiated rather than suppressed cocaine-CPP. These results suggest that repeated social defeat and repeated swim stress acted similarly.

We next asked if exposure to SDS would affect cocaineCPP by a prodynorphin-dependent mechanism using prodynorphin KO mice and their WT littermates. Previously, DYN(-I-) mice showed the same cocaine preference in the CPP chamber as $\mathrm{WT} \mathrm{C} 57 \mathrm{Bl} / 6$ mice or matched WT littermate controls (McLaughlin et al, 2003).

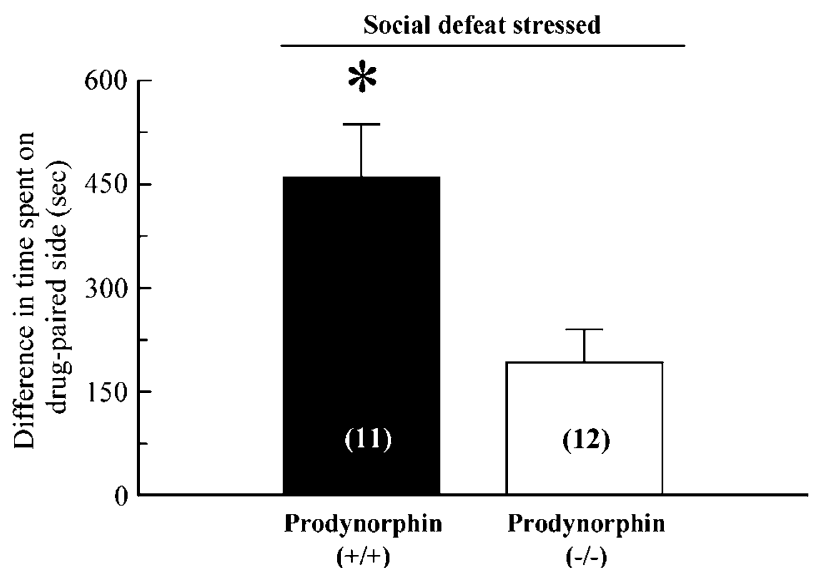

Figure 4 Disruption of prodynorphin gene prevents the SDS-induced potentiation of cocaine-CPP. Prodynorphin gene knockout or WT littermate mice were exposed to 3-day SDS and then used in cocaineCPP assays as detailed in Figure $3 a$ and 'Materials and methods.' All animals demonstrated cocaine-CPP after conditioning that was significantly greater than preference during the preconditioning trial. However, SDS-exposed WT littermates demonstrated cocaine-CPP that was approximately double the preference responses of the social defeat-stressed prodynorphin $\mathrm{KO}$ mice. * significant difference in matching cocaine-CPP response of SDS-exposed prodynorphin WT vs gene disrupted mice, $p<0.05$ for all as determined by Student's t-test. Bars each represent $n=11-12$ animals. 
Consistent with our previous findings using forced swim, WT littermates exposed to repeated SDS developed significantly greater cocaine-CPP than SDS-exposed $\operatorname{DYN}(-/-)$ mice $(p>0.05$, Student's $t$-test, Figure 4$)$. The results show that SDS produced significantly less cocaineCPP in mice lacking DYN.

\section{DISCUSSION}

The current studies support the hypothesis that stressinduced release of endogenous DYN and subsequent activation of the KOR mediates a component of the stressinduced potentiation of the cocaine response. Repeated FSS was chosen as a stressor in previous studies, where immobility is assumed to reflect a cognitive/emotional state of 'despair' (Porsolt et al, 1977; Pliakas et al, 2001). However, a variety of behavioral studies suggest that immobility in the forced-swim test actually reflects a learned adaptation to stress, perhaps as a means to conserve energy rather than an impairment of coping responses (Holmes, 2003; West, 1990). The current study chose SDS, a naturalistic stress model characterized by aggressive, unpredictable interactions, as repeated swim stress and repeated SDS differ in important ways. Animals subjected to SDS have characteristic subordinate behavioral patterns, decreased food intake with weight loss, and show decreased social behavior (aggression, mating) (Blanchard et al, 1995). In contrast, repeated swim stress usually only causes hypoactivity (Holmes, 2003). FSS-induced immobility is qualitatively different from submissive immobile behavior. These data suggest FSS and SDS may involve different neural circuits and produce different types of adaptive responses. Similar to repeated swim stress, SDS has also been validated as an animal model of depression (Dalvi and Lucki, 1999), but it has more apparent relevance to humans. Many of the changes observed in animals repeatedly or chronically exposed to social defeat resemble the symptoms of depression in humans (Bjorkqvist, 2001). Understanding how the brain responds to repeated social defeat in animals may prove useful in understanding the effects of social stress in humans.

Our data demonstrate that $\mathrm{C} 57 \mathrm{Bl} / 6$ mice subjected to repeated SDS over 3 days showed a characteristic stressinduced immobility and defeated-postural response, as well as SIA. Either daily pretreatment with the KOR antagonist nor-BNI or prodynorphin gene-disruption blocked the SIA and significantly reduced the stress-induced immobility after the first day. Although the reduction in immobility is small $(20-35 \%)$, the effect is consistent with that produced by established antidepressant drugs (Lucki et al, 2001). Either daily pretreatment with the KOR antagonist nor-BNI or prodynorphin gene-disruption blocked the SIA and significantly reduced the stress-induced immobility after the first day. The results using kappa receptor antagonism and prodynorphin gene-disruption are consistent and support the hypothesis that stress-induced release of endogenous DYNs activate the KOR to mediate the behavioral effects observed; however, interpretation of results using $\mathrm{KO}$ mice must be done cautiously as compensatory changes in the absence of the deleted gene may have influenced the results. In addition, prodynorphin- derived peptides can act at sites other than KORs, thus their deletion may also be affecting other signaling systems (see McLaughlin et al, 2003).

These results on locomotion with SDS are consistent with prior reports using repeated swim stress (Pliakas et al, 2001; McLaughlin et al, 2003). The lack of effects of DYN/KOR system on immobility on day 1 suggests that an alternative mechanism may mediate early social defeat postures. Several studies have implicated the mediation of corticotropin-releasing factor (CRF) in the stress behavioral responses and stress-related drug abuse (Koob, 1999; Erb et al, 1998). Also, a line of results have suggested that brainderived neurotrophic factor (BDNF) could be a stressresponsive intercellular messenger, thus possibly mediating cocaine relapse (Givalois et al, 2004; Lu et al, 2004). Social defeat behavior over time may well be mediated by multiple neurotransmitter systems/pathways. More research is required to clarify the underlying temporal relationships. Conceivably, this issue may prove important in developing appropriate medications, where KOR antagonists may be of help only in chronic, rather than acute, stressful states.

Stress has been shown to increase drug craving (Shaham et al, 2003; Sanchez et al, 2003; Covington and Miczek, 2001; Haile et al, 2001). However, a facilitating role of the kappa opioid system remains surprising as acute kappa receptor activation has been known to reduce reinforcing effects of cocaine and cocaine-induced increases in mesolimbic dopamine levels (Mori et al, 2002; Mello and Negus, 1998; Zhang et al, 2004; Spanagel et al, 1992; Glick et al, 1995). Based on those data, it was reasonable to expect that the stress-induced activation of the endogenous DYN/kappa system would reduce the reinforcing properties of cocaine. However, our data showed that SDS-exposed mice conditioned with cocaine revealed significant potentiation of place-preference for the drug-paired chamber over the responses of unstressed mice. These findings are consistent with our previous results showing that chronic repeated swim stress induced a significant potentiation of cocaineCPP mice (McLaughlin et al, 2003). There are several factors that may account for the apparently conflicting results obtained by stress-induced activation and pharmacological activation of the kappa opioid system. A key variable may be differences between the experimental protocols of the assorted investigators. Alternatively, the actions of endogenous DYNs released by stress may be different from those produced by the pharmacological activation of kappa receptors. Finally, repeated activation of the endogenous kappa opioid system by chronic stress may induce kappa receptor desensitization that might result in different responses to cocaine than an acute administration of kappa opioid agonists (McLaughlin et al, 2005).

In conclusion, chronic SDS induced-behaviors were shown to be blocked by kappa receptor antagonism and prodynorphin gene disruption. These results suggest that stress-induced release of endogenous DYNs and subsequent activation of the KOR may mediate the behavioral effects observed. Repeated exposure to social stress acted similarly to stress induced by repeated forced swim, and both stressors increased the reinforcing properties of cocaine by a DYN/kappa-dependent mechanism. The results support the speculation that kappa receptor antagonists may be therapeutically useful tools potentially able to ameliorate 
the adverse effects of chronic stress and reduce the risk of relapse in drug-addicted individuals.

\section{ACKNOWLEDGEMENTS}

Dr Uwe Hochgeschwender generously provided the prodynorphin knockout mice. Joe Novak performed the mouse genotyping. The work was supported by USPHS grants and RO1-DA11672 and PO1-DA15916 to CC and RO3 DA16656 to JPM from the National Institute on Drug Abuse. JV was supported by the Physician Scientist Summer Training Program.

\section{REFERENCES}

Blanchard DC, Spencer RL, Weiss SM, Blanchard RJ, McEwen B, Sakai RR (1995). Visible burrow system as a model of chronic social stress: behavioral and neuroendocrine correlates. Psychoneuroendocrinology 20: 117-134.

Bjorkqvist K (2001). Social defeat as a stressor in humans. Physiol Behav 73: 435-442.

Carlezon Jr WA, Thome J, Olson VG, Lane-Ladd SB, Brodkin ES, Hiroi $\mathrm{N}$ et al (1998). Regulation of cocaine reward by CREB. Science 282: 2272-2275.

Chefer VI, Czyzyk T, Bolan EA, Moron J, Pintar JE, Shippenberg TS (2005). Endogenous kappa-opioid receptor systems regulate mesoaccumbal dopamine dynamics and vulnerability to cocaine. J Neurosci 25: 5029-5037.

Covington III HE, Miczek KA (2001). Repeated social-defeat stress, cocaine or morphine. Effects on behavioral sensitization and intravenous cocaine self-administration 'binges'. Psychopharmacology (Berlin) 158: 388-398.

Cunningham CL, Henderson CM, Bormann NM (1998). Extinction of ethanol-induced conditioned place preference and conditioned place aversion: effects of naloxone. Psychopharmacology (Berlin) 139: 62-70.

Dalvi A, Lucki I (1999). Murine models of depression. Psychopharmacology (Berlin) 147: 14-16.

Epstein DH, Preston KL (2003). The reinstatement model and relapse prevention: a clinical perspective. Psychopharmacology (Berlin) 168: 31-41.

Erb S, Shaham Y, Stewart J (1998). The role of corticotropinreleasing factor and corticosterone in stress- and cocaineinduced relapse to cocaine seeking in rats. J Neurosci 18: 5529-5536.

Haile CN, GrandPre T, Kosten TA (2001). Chronic unpredictable stress, but not chronic predictable stress, enhances the sensitivity to the behavioral effects of cocaine in rats. Psychopharmacology (Berlin) 154: 213-220.

Holmes PV (2003). Rodent models of depression: reexamining validity without anthropomorphic inference. Crit Rev Neurobiol 15: 143-174.

Givalois L, Naert G, Rage F, Ixart G, Arancibia S, Tapia-Arancibia L (2004). A single brain-derived neurotrophic factor injection modifies hypothalamo-pituitary-adrenocortical axis activity in adult male rats. Mol Cell Neurosci 27: 280-295.

Glick SD, Maisonneuve IM, Raucci J, Archer S (1995). Kappa opioid inhibition of morphine and cocaine self-administration in rats. Brain Res 681: 147-152.

Goeders NE (2002). Stress and cocaine addiction. J Pharmacol Exp Ther 301: 785-789.

Kabbaj M, Norton CS, Kollack-Walker S, Watson SJ, Robinson TE, Akil H (2001). Social defeat alters the acquisition of cocaine self-administration in rats: role of individual differences in cocaine-taking behavior. Psychopharmacology (Berlin) 158: 382-387.
Koob GF (1999). Stress, corticotropin-releasing factor, and drug addiction. Ann NY Acad Sci 897: 27-45.

Lu L, Dempsey J, Liu SY, Bossert JM, Shaham Y (2004). A single infusion of brain-derived neurotrophic factor into the ventral tegmental area induces long-lasting potentiation of cocaine seeking after withdrawal. J Neurosci 24: 1604-1611.

Lucki I, Dalvi A, Mayorga AJ (2001). Sensitivity to the effects of pharmacologically selective antidepressants in different strains of mice. Psychopharmacology (Berlin) 155: 315-322.

Mague SD, Pliakas AM, Todtenkopf MS, Tomasiewicz HC, Zhang Y, Stevens Jr WC et al (2003). Antidepressant-like effects of kappa-opioid receptor antagonists in the forced swim test in rats. J Pharmacol Exp Ther 305: 323-330.

McLaughlin JP, Marton-Popovici M, Chavkin C (2003). Kappa opioid receptor antagonism and prodynorphin gene disruption block stress-induced behavioral responses. J Neurosci 23: 5674-5683.

McLaughlin JP, Land BB, Li S, Pintar JE, Chavkin C (2005). Prior activation of kappa opioid receptors by $\mathrm{u} 50488$ mimics repeated forced swim stress to potentiate cocaine place preference conditioning. Neuropsychopharmacology (in press).

Mello NK, Negus SS (1998). Effects of kappa opioid agonists on cocaine- and food-maintained responding by rhesus monkeys. J Pharmacol Exp Ther 286: 812-824.

Miczek KA (1979). A new test for aggression in rates without aversive stimulation: differential effects of $D$-amphetamine and cocaine. Psychopharmacology (Berlin) 60: 253-259.

Miczek KA, Covington III HE, Nikulina EM, Hammer RP (2004). Aggression and defeat: persistent effects on cocaine selfadministration and gene expression in peptidergic and aminergic mesocorticolimbic circuits. Neurosci Biobehav Rev 27: 787-802.

Mori T, Nomura M, Nagase H, Narita M, Suzuki T (2002). Effects of a newly synthesized kappa-opioid receptor agonist, TRK-820, on the discriminative stimulus and rewarding effects of cocaine in rats. Psychopharmacology (Berlin) 161: $17-22$.

Newton SS, Thome J, Wallace TL, Shirayama Y, Schlesinger L, Sakai N et al (2002). Inhibition of cAMP response elementbinding protein or dynorphin in the nucleus accumbens produces an antidepressant-like effect. J Neurosci 22: 1088310890.

Nikulina EM, Covington III HE, Ganschow L, Hammer Jr RP, Miczek KA (2004). Long-term behavioral and neuronal crosssensitization to amphetamine induced by repeated brief social defeat stress: fos in the ventral tegmental area and amygdala. Neuroscience 123: 857-866.

Pliakas AM, Carlson RR, Neve RL, Konradi C, Nestler EJ, Carlezon Jr WA (2001). Altered responsiveness to cocaine and increased immobility in the forced swim test associated with elevated cAMP response element-binding protein expression in nucleus accumbens. J Neurosci 21: 7397-7403.

Porsolt RD, Bertin A, Jalfre M (1977). Behavioural despair in mice: a primary screening test for antidepressants. Arch Int Pharmacodyn 229: 327-336.

Rodgers RJ, Randall JI (1986). Acute non-opioid analgesia in defeated male mice. Physiol Behav 36: 947-950.

Sanchez CJ, Bailie TM, Wu WR, Li N, Sorg BA (2003). Manipulation of dopamine D1-like receptor activation in the rat medial prefrontal cortex alters stress- and cocaine-induced reinstatement of conditioned place preference behavior. Neuroscience 119: 497-505.

Shaham Y, Erb S, Stewart J (2000). Stress-induced relapse to heroin and cocaine seeking in rats: a review. Brain Res Brain Res Rev 33: 13-33.

Shaham Y, Shalev U, Lu L, De Wit H, Stewart J (2003). The reinstatement model of drug relapse: history, methodology and major findings. Psychopharmacology (Berlin) 168: 3-20. 
Sharifi N, Diehl N, Yaswen L, Brennan MB, Hochgeschwender U (2001). Generation of dynorphin knockout mice. Mol Brain Res 86: $70-75$.

Sinha R, Catapano D, O’Malley S (1999). Stress-induced craving and stress response in cocaine dependent individuals. Psychopharmacology (Berlin) 142: 343-351.

Spanagel R, Herz A, Shippenberg TS (1992). Opposing tonically active endogenous opioid systems modulate the mesolimbic dopaminergic pathway. Proc Natl Acad Sci USA 89: 2046-2050.

Spina MG, Basso AM, Zorrilla EP, Heyser CJ, Rivier J, Vale W et al (2000). Behavioral effects of central administration of the novel CRF antagonist astressin in rats. Neuropsychopharmacology 22: 230-239.

Stewart J (2003). Stress and relapse to drug seeking: studies in laboratory animals shed light on mechanisms and sources of long-term vulnerability. Am J Addict 12: 1-17.

Vaught JL, Takemori AE (1979). Differential effects of leucine and methionine enkephalin on morphine-induced analgesia, acute tolerance and dependence. J Pharmacol Exp Ther 208: 86-90.

West AP (1990). Neurobehavioral studies of forced swimming: the role of learning and memory in the forced swim test. Prog Neuropsychopharmacol Biol Psychiatry 14: 863-877.

Zhang Y, Butelman ER, Schlussman SD, Ho A, Kreek MJ (2004). Effect of the kappa opioid agonist R-84760 on cocaine-induced increases in striatal dopamine levels and cocaine-induced place preference in C57BL/6J mice. Psychopharmacology (Berlin) 173: $146-152$. 